\title{
Penggunaan Google Form sebagai Alat Evaluasi Pelajaran Fisika Kelas X
}

\author{
Bunga Yuliana, *Syifaul Gummah, Baiq Azmi Sukroyanti \\ Pendidikan Fisika, FSTT Universitas Pendidikan Mandalika, Indonesia \\ Corresponding email: syifaulgummah@undikma.ac.id
}

\author{
Sejarah Artikel \\ Dikirim: November 2021 \\ Diterima: Desember 2021 \\ Dipublikasi: Desember \\ 2021
}

\section{Kata Kunci}

Google form;

Instrument;

Kinerja siswa

\begin{abstract}
Abstrak
Tujuan penelitian ini adalah untuk mengetahui prosedur pembuatan angket online dengan Google Form sebagai instrumen kinerja siswa dan respon siswa dalam menggunakannya. Metode deskriptif kualitatif dilakukan dalam penelitian ini menggunakan kuesioner dan studi dokumentasi. Partisipan dalam penelitian ini adalah siswa jurusan IPA. Hasil penelitian ini menunjukkan bahwa prosedur pengembangan angket penilaian kinerja siswa pada proses pembelajaran menggunakan Google Form dimulai dari perencanaan, pembuatan, penerbitan dan pemberian petunjuk penggunaan. Data tanggapan siswa menunjukkan bahwa sebagian besar siswa suka menggunakan angket online (65\%), mudah diakses (40\%), waktu menjadi lebih hemat $(40 \%)$, hemat kertas $(50 \%)$, tahu cara menggunakannya $(55 \%)$, tampilan mudah dimengerti (65\%), Bahasa kuesioner sesuai $(65 \%)$, menjawab lebih mudah menggunakan google form (50\%), tertarik menjawab pertanyaan dengan google form (70\%). Jadi, Google Form sangat berguna bagi guru dan siswa untuk mengumpulkan data kinerja siswa.
\end{abstract}

\section{Using Google Forms as an Evaluation Tool for Class X Physics Lessons}

\section{Article History}

Received: November 2021

Accepted: December 2021

Published: December 2021

Key Words

Google Form;

Instrument;

Student performances

How to cite this article?

\begin{abstract}
The purpose of this study to know the procedure of creating online questionnaire with Google Form as instrument of student performances and student responding to using it. Analysis kualitatif descriptive method was implemented within study by using a set of questionnaire and documentation study. The participants for this study are students of department of science. The results of this study indicated that procedure of development student performance assessment questionnaire on the learning process using Google Form started from planning, creating, publishing and providing usage instructions. Students response data showed that most students like to use an online questionnaire (65\%), easily accessible (40\%), time becomes more efficient (40\%), save paper (50\%), know how to use it (55\%), the display is easily understandable (65\%), Language of questionnaires are appropriate (65\%), answer easier using google form (50\%), interested answering question with google form (70\%). So, Google Form is very useful for teachers and students to collect data student performance.
\end{abstract}

Yuliana, B., Gummah, S., \& Sukroyanti, B. (2021). Penggunaan Google Form sebagai Alat Evaluasi Pelajaran Fisika Kelas X. Lensa: Jurnal Kependidikan Fisika, 9(2), 178-183. doi:https://doi.org/10.33394/j$\underline{1 \mathrm{kf} . \mathrm{v} 9 \mathrm{i} 2.4691}$

\section{PENDAHULUAN}

Pendidikan secara umum bertujuan membantu manusia menemukan akan hakikat kemanusiaanya. Dengan adanya pendidikan yang diungkapkan Sumantri (2017) yaitu diharapkan manusia mampu menyadari potensi yang ia miliki sebagai makhluk yang berpikir. Salah satu kebijakan umum pembangunan pendidikan di Indonesia adalah peningkatan mutu pendidikan.

Berdasarkan paparan tersebut maka dapat disimpulkan bahwa pendidikan merupakan salah satu wadah atau lembaga untuk membentuk manusia yang mampu mengembangkan potensi diri. Oleh sebab itu, dengan mengembangkan potensi diri peserta 
didik mampu mengembangkan pengendalian diri, kepribadian, kecerdasan, keterampilan maupun akhlak yang dimilikinya, sehingga peserta didik mampu bermasyarakat dan bernegara dengan baik.

Untuk dapat mengetahui keberhasilan dari pencapaian tujuan pendidikan agar sesuai dengan tujuan pendidikan nasional dalam Undang-undang, perlu diadakannya evaluasi. Sebagaimana yang dikemukakan Gilbert Sax dalam Arifin (2009:5) bahwa "evaluation is a process thought which a value judgement or decision is made from a variety of observations and from the background and training of the evaluator". Pengertian tersebut ialah pada hakikatnya evaluasi adalah suatu proses yang sistematis dan berkelanjutan untuk menentukan kualitas (nilai dan arti) dari sesuatu, berdasarkan kepada pertimbangan dan kriteria tertentu dalam rangka pembuatan suatu keputusan.

Mata pelajaran Fisika salah satu mata pelajaran yang dapat dimanfaatkan dengan menggunakan teknologi dalam pembelajaran.Termasuk dalam kegiatan evaluasi pembelajaran dapat memanfaatkan peran media untuk merubah iklim belajar.Mengingat Kompetensi Fisika tentang Standar Kompetensi Lulusan untuk Satuan Pendidikan Dasar dan Menengah untuk mata pelajaran Fisika diantaranya mendengarkan, berbicara, membaca dan menulis (Peraturan Menteri Pendidikan Nasional Nomor 23 Tahun 2006).

Karakteristik mata pelajaran Fisika yang memiliki banyak angka, rumus dan lainlain, membutuhkan kemampuan menyimak dan menghafal yang baik untuk dapat menerima informasi tersebut.

Pada kenyataanya, fenomena yang terdapat pada pembelajaran Fisika di Sekolah Menengah Atas adalah (1) Guru cenderung menggunakan metode konvensional seperti metode ceramah, siswa mengerjakan lembar kerja siswa dan ujian tertulis; (2) Kemampuan guru merancang dan memanfaatkan media masih sangat kurang, terlihat pada proses pembelajaran yang masih bersifat verbal dan klasikal; (3) Sarana dan prasarana sudah tersedia, seperti laboratorium komputer, proyektor disetiap kelas sampai koneksi wi-fi, namun sarana dan prasarana tersebut belum dioptimalkan penggunaanya sebagai penunjangpembelajaran; dan (3) Media yang dimanfaatkan oleh guru ketika pembelajaran cenderung media konvensional berupa papan tulis dan media cetak khususnya buku paket, lembar kerja siswa, dan tes tertulis.

Mengingat sekolah tersebut adalah sekolah negeri yang memiliki standar fasilitas penunjang untuk pembelajaran seperti laboratorium komputer, wi-fi, proyektor disetiap kelas, dan pendukung lainnya.Jika fasilitas di sekolah seperti komputer dan koneksi internet dimanfaatkan dengan baik, maka menjadikan peluang bagi peneliti untuk mengembangkan sistem evaluasi berupa alat evaluasi yang memanfaatkan teknologi komputer dan internet.Evaluasi tersebut ialah evaluasi online yang menggunakan website Google Form sebagai alat evaluasi.Alat evaluasi ini berbasis komputer dan koneksi internet yang bertujuan untuk membantu guru dalam pelaksanaan dan persiapan ujian yang diadakan di sekolah dan hasil penilaian siswa dapat segera diolah dan diketahui hasilnya.Selain itu, dengan menggunakan Google Form dapat menganalisis butir soal yang dapat ditindak lanjut oleh guru untuk mengetahui siswa yang kurang memahami terhadap materi pelajaran yang diberikan sebelumnya.

Sejalan dengan hal tersebut yang dinyataka oleh Syahputra (2017) yaitu dalam kegiatan pembelajaran sudah seharusnya dapat menggunakan peran teknologi yang memudahkan dalam kegiatan pembelajaran. Berbagai media bahan ajar, metode pembelajaran sampai kepada kegiatan evaluasi pembelajaran, dapat difasilitasi dengan menggunakan teknologi saat ini. Dengan demikian, seharusnya dapat membawa dampak yang sangat baik yang dapat memecahkan masalah pembelajaran.Salah satu teknologi pembelajaran adalah Google Form adalah layanan online, dan untuk mengumpulkan data, komentar, yang nantinya dapat disusun mengunakan spreadsheet. 
Berdasarkan kondisi diatas, maka peneliti berinisiatif membuat tes online Fisika berbasis google form, karena google form lebih fleksibel dibanding teskonvensional. Biasanya penyajian tes online berbasis google form untuk tesmudah diserap dan di mengerti dengan baik oleh siswa sehingga akan sangatmembantu dalam proses tes fisika.

\section{METODE}

Jenis penelitian ini adalah penelitian kualitatif deskriptif, yaitu data yang dikumpulkan berbentuk kata-kata, gambar, bukan angka-angka.Menurut Bogdan dan Taylor, sebagaimana yang dikutip oleh Lexy J. Moleong, penelitiankualitatif adalah prosedur penelitian yang menghasilkan datadeskriptif berupa kata-kata tertulis atau lisan dari orang-orangdan perilaku yang diamati.

Sementara itu, penelitian deskriptif adalah suatu bentuk penelitian yang ditujukan untuk mendeskripsikan atau menggambarkan fenomena-fenomena yang ada, baik fenomena alamiah maupun rekayasa manusia.

Adapun tujuan dari penelitian deskriptif adalah untuk membuat perencanaan secara sistematis, faktual, dan akurat mengenai fakta dan sifat populasi atau daerah tertentu. Penelitian ini digunakan untuk mengetahui bagaimana penggunaan google form sebagai alat penilaian soal evaluasi.

\section{Instrumen Penelitian}

Menurut Notoatmodjo (2018) instrument penelitian adalah alat-alat yang akan digunakan untuk pengumpulan data. Instrument penelitian dapat berupa: kuesioner, observasi, formulir-formulir lain yang berkaitan dengan pencatatan data dan sebagainya. Dalam penelitian ini instrument yang digunakan antara lain.

1. Instrumen Observasi

Instrument observasi merupakan pedoman peneliti dalam mengadakan pengamatan dan pencarian sistematik terhadap fenomena yang diteliti.Pedoman ini berkaitan dengan situasi dan kondisi di sekolah.

2. Instrumen Dokumentasi

Instrumen dokumentasi adalah alat bantu yang digunakan untuk mengumpulkan data. Dalam penelitian ini, dokumentasi yang digunakan adalah screenshoot soal evaluasi dan anket pada halaman google form.

3. Instrumen tes

Instrument tes yang digunakan dalam penelitian ini adalah tes dalam bentuk soal pilihan ganda karena dirasa mudah untuk mengidentifikasi kemampuan siswa.Penilaian dari hasil tes ini berdasarkan kemampuan siswa dalam mengomunikasikan soal kedalam kalimat matematika, dari langkah-langkah yang dikerjakan oleh siswa kita dapat melihat kemampuan dari siswa. Tes soal pilihan ganda yang diberikan kepada siswa berjumlah 20 soal tentang gaya dan energi. Penyusunan butir-butir soal mengacu pada kriteria komunikasi matematika yang harus dikuasai siswa yang sebelumnya peneliti mengonsultasikan terlebih dahulu ke dosen pembimbing dan guru mata pelajaran ditempat penelitian.

\section{Teknik Analisis Data}

Data yang dianalisis adalah data yang diperoleh dari soal tes dan angket tanggapan siswa terhadap penggunaan Google Form. Berdasarkan hasil dari analisis data angket tanggapan siswa terhadap penggunaan google form, peneliti menemukan bahwa mayoritas siswa setuju dilihat dari soal tes dan angket tanggapan siswa pada Google Form.

Setiap penelitian peneliti melakukan teknik analisis data dengan cara yang berbedabeda. Dalam hal ini teonik analisis penelitian ini dilaksanakan dengan: 
1. Mengelompokkan rata-rata skor jawaban siswa pada angket berdasarkan kategori skala likert

2. Mencari persentase hasil tanggapan siswa

3. Menginterpretasi jawaban siswa berdasarkan hasil persentase

\section{HASIL DAN PEMBAHASAN}

\section{Analisis Hasil Tes Soal Evaluasi Siswa Menggunakan Google Form}

Pada soal nomor 1 (Gambar 1), pernyataan yang benar tentang energy adalah pilihan ganda $(C)$ energy tidak dapat diciptakan dan tidak dapat diam. Pada soal ini siswa yang menjawab benra berjumlah $60 \%$, sedangkan yang menjawab salah berjumlah $30 \%$ dan $10 \%$, karena siswa ada yang memilih jawaban pilihan ganda (A) energy merupakan zat karena memiliki massa dan ruang, dan pilihan gfganda (D) energy memiliki satuan newton. Pada jawaban (A) dan (E) adalah jawaban yang salah.

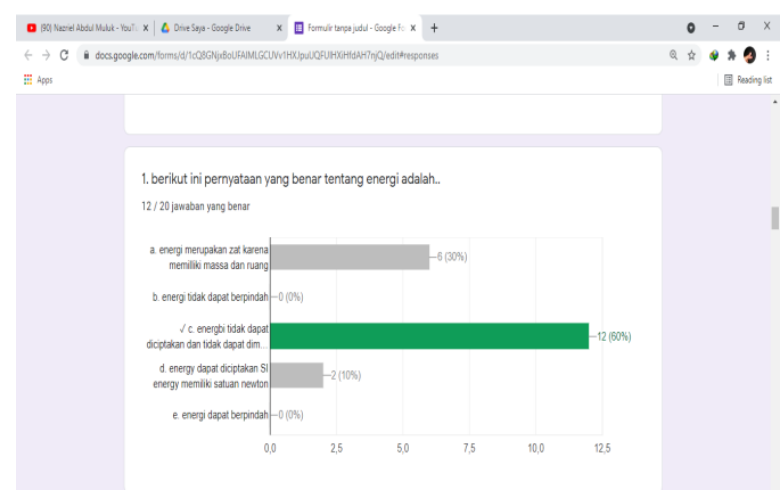

Gambar 1. Soal nomor 1

Soal yang benar dari soal nomor 3 di atas adalah (B) gaya konservatif. Dan dalam hal ini siswa yang menjawab (B) berjumlah $85 \%$, dan ada juga yang menjawab (A) gaya gerak berjumlah $10 \%$, dan (D) gaya tarik adalah jawaban yang tidak benar. Sehingga sebagian besar dari 20 jumlah siswa menjawab dengan benar.Seperti yang terlihat pada hasil di atas.

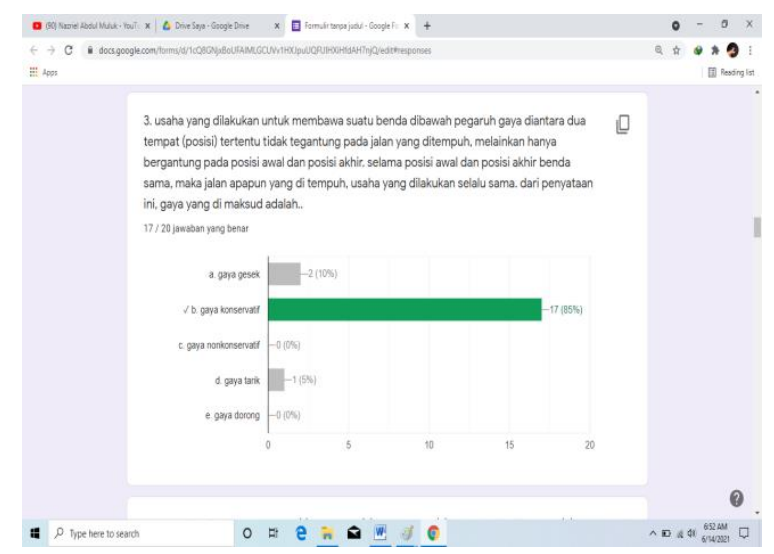

Gambar 2. Soal nomor 3

Apabila ada pertanyaan yang sering terlewatkan atau paling banyak dijawab salah, maka di Google Form akan ditampilkan seperti pada Gambar 3. 


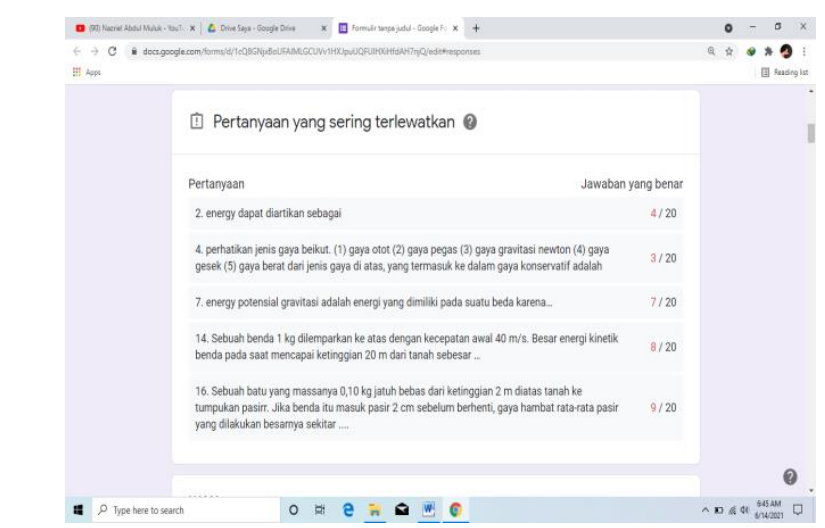

Gambar 3. Pertanyaan yang sering terlewatkan

\section{Respon Siswa SMA N 1 Praya Timur terhadap Penggunaan Google Form sebagai Alat Evaluasi Soal Fisika Kelas X}

Sumber daya siswa menjadi faktor penting dalam kesuksesan penggunaan google form sebagai alat evaluasi soal. Adapun ditinjau dari kompetensi siswa dalam menggunakan google form menunjukkan bahwa siswa telah mampu menggunakan computer, dan sebagia siswa telah memiliki email google dan mereka juga mampu menggunakan internet untuk mengakses website dan bekomunikasi menggunakan email.

Hasil respon siswa tersebut menunjukkan bahwa mayoritas siswa memberikan respon setuju terhadap penggunaan google form sebagai alat penilaian soal evaluasi fisika pada kelas $\mathrm{X}$ yang ada pada Table 1 .

Tabel 1. Mayoritas siswa memberikan respon yang positif

\begin{tabular}{clcc}
\hline No & \multicolumn{1}{c}{ Keterangan } & Nilai & \% \\
\hline 1 & Sangat Setuju & 240 & $26,67 \%$ \\
2 & Setuju & 485 & $53,89 \%$ \\
3 & Kurang Setuju & 155 & $17,22 \%$ \\
4 & Tidak Setuju & 20 & $2,22 \%$ \\
\hline
\end{tabular}

Table 1 menujukkan bahwa respon siswa yang positif terhadap penggunaan google form sebagai alat penilaian soal evaluasi fisika siswa kelas. Menyimpulkan bahwa 26,67 $\%$ siswa sangat setuju terhadap penggunaan google form sebagai alat penilaia soal evaluasi, 53,89 \% siswa setuju terhadap penggunaan google form sebagai alat penilaian soal evaluasi, 17,22 \% siswa kurang setuju terhadap penggunaan google form sebagai alat penilaian soal evaluasi fisika, dan 2,22 \% siswa tidak setuju tehadap penggunaan google form sebagai alat penilaian soal evaluasi fisika.

\section{KESIMPULAN}

Berdasarkan hasil penelitian dan analisis data dan pembahasan bab IV maka dapat disimpulkan bahwa respon siswa terhadap penggunaan google form sebagai alat penilaian soal evaluasi fisika siswa kelas X SMA N 1 Praya Timur Kabupaten Lombok Tengah menunjukan bahwa mayoritas siswa setuju dengan penggunaan google form dengan presentase $53,89 \%$.

\section{DAFTAR PUSTAKA}

Abdurrahmat Fathoni, 2006.Metodologi Penelitian dan Teknik Penyusunan Skripsi.Jakarta: PT Rineka Cipta.

Daryanto,2010.Media Pembelajaran.Bandung: Satu Nusa Studio.

E.Mulyasa, 2011.Praktik Penelitian Tindakan Kelas. Bandung: Remaja Rosdakarya. 
Husein Hamdan, 2016. Penggunaan Google From Sebagai Penilaian Kinerja Dosen di Prodi UNISKA Muhammad Arsyad Al-Banjari. AL- Bidayah: Jurnal Pendidikan Dasar Islam. Vol:8.

Lexy. J. Moleong, 2000.Metodologi Penelitian Kualitatif. Bandung: PT Remaja Rosdakarya.

Muhammad S. Sumantri,2017. Pengantar Pendidikan.Tangerang Selatan: Universitas Terbuka,

Mulyo Raharjo, 2012. Model Pembelajaran. Yogyakarta: Gava Media.

Muhammad Candra Syahputra, 2017.Guru Kreatif Pake TIK dong.Bandar Lampung: Harakindo Publishing.

Sugiono, 2009. Metode Penelitian Kuantitatif, Kualitatif, dan $R \& D$. Bandung: Alpabeta.

Sudarwan Danim, 2002. Menjadi Peneliti Kualitatif Rancangan Metodologi, Presentasi, dan Publikasi Hasil Penelitian untuk Mahasiswa dan Penelitian Pemula Bidang Ilmu Sosial, Pendidikan, dan Humaniora. Bandung: Remaja Rosdakarya.

Saifuddin Azwar. 2013. Metode Peelitian. Yogyakarta: Pustaka Pelajar.

Vivin, 2016.Membuuat Alamat Gmail.Dikutip dari https://support. Google.com/mailtopic=3394144 pada tanggal 20juni 2016.

Muhammad Rizal Fauzi (2014), Penggunaan Google Form sebagai Alat Evaluasi

Pembelajaran pada Mata Pelajaran Bahasa Indonesia, (Bandung: Universitas Pendidikan Indonesia, dikutip dari repository.upi.edu.

Trisnaningsih, Sri. (2011). "Faktor-Faktor yang Mempengaruhi Kinerja Dosen Akuntansi." Journal Of Accounting AndAuditing, 8.1, hlm. 83-94.

Zainal Arifin. (2013), Evaluasi Pembelajaran, (Bandung: PT Remaja Rosdakarya).

Batubara, H.H. (2016). Penggunaan Google Form SebagaiAlat Penilaian Kinerja Dosen di Program Studi PGMI UNISKA Muhammad Arsyad Al Banjari.Jurnal Al-Bidayah 8 (1): $39-50$ 